\title{
Benzene in the environment: an assessment of the potential risks to the health of the population
}

\author{
R Duarte-Davidson, C Courage, L Rushton, L Levy
}

\begin{abstract}
Objectives-Benzene has long been recognised as a carcinogen and recent concern has centred on the effects of continuous exposure to low concentrations of benzene both occupationally and environmentally. This paper presents an overview of the current knowledge about human exposure to benzene in the United Kingdom population based on recently published data, summarises the known human health effects, and uses this information to provide a risk evaluation for sections of the general United Kingdom population. Method-Given the minor contribution that non-inhalation sources make to the overall daily intake of benzene to humans, only exposure from inhalation has been considered when estimating the daily exposure of the general population to benzene. Exposure of adults, children, and infants to benzene has been estimated for different exposure scenarios with timeactivity patterns and inhalation and absorption rates in conjunction with measured benzene concentrations for a range of relevant microenvironments. Exposures during refuelling and driving, as well as the contribution of active and passive tobacco smoke, have been considered as part of the characterisation of risk of the general population.
\end{abstract}

Results-Infants ( $<1$ years old), the average child (11 years old), and nonoccupationally exposed adults, receive average daily doses in the range of 15-26, 29-50, and 75-522 $\mu \mathrm{g}$ of benzene, respectively, which correspond to average ranges to benzene in air of $3.40-5.76 \mu \mathrm{g} / \mathrm{m}^{3}$, 3.37-5.67 $\mu \mathrm{g} / \mathrm{m}^{3}$, and $3.7-41 \mu \mathrm{g} / \mathrm{m}^{3}$ for infants, children, and adults, respectively. Infants and children exposed to environmental tobacco smoke have concentrations of exposure to benzene comparable with those of an adult passive smoker. This is a significant source of exposure as a 1995 United Kingdom survey has shown that $47 \%$ of children aged $2-15$ years live in households where at least one person smokes. The consequence of exposure to benzene in infants is more significant than for children or adults owing to their lower body weight, resulting in a higher daily intake for infants compared with children or non-smoking adults. A worst case scenario for exposure to benzene in the general population is that of an urban smoker who works adjacent to a busy road for 8 hours/day-for example, a maintenance worker-who can receive a mean daily exposure of about $820 \mu \mathrm{g}$ (equal to an estimated exposure of $\left.41 \mu \mathrm{g} / \mathrm{m}^{3}\right)$. The major health risk associated with low concentrations of exposure to benzene has been shown to be leukaemia, in particular acute non-lymphocytic leukaemia. The lowest concentration of exposure at which an increased incidence of acute nonlymphocytic leukaemia among occupationally exposed workers has been reliably detected, has been estimated to be in the range of $32-80 \mathrm{mg} / \mathrm{m}^{3}$. Although some studies have suggested that effects may occur at lower concentrations, clear estimates of risk have not been determined, partly because of the inadequacy of exposure data and the few cases.

Conclusions-Overall the evidence from human studies suggests that any risk of leukaemia at concentrations of exposure in the general population of $3.7-42 \mu \mathrm{g} / \mathrm{m}^{3}-$ that is at concentrations three orders of magnitude less than the occupational lowest observed effect level-is likely to be exceedingly small and probably not detectable with current methods. This is also likely to be true for infants and children who may be exposed continuously to concentrations of $3.4-5.7 \mu \mathrm{g} / \mathrm{m}^{3}$. As yet there is no evidence to suggest that continuous exposures to these environmental concentrations of benzene manifest as any other adverse health effect.

(Occup Environ Med 2001;58:2-13)

Keywords: risk assessment; benzene; environment

Benzene is a well known genotoxic carcinogen and has caused great concern historically as an occupational health hazard. Progressive reduction in use of benzene and continual reduction in the occupational exposure limits has ensured that effects due to high concentrations of benzene in the workplace should no longer present a serious problem except in the case of 
accidents. Current concern is centred on the effects of long term continuous low concentrations of exposure to benzene both occupationally and environmentally.

Benzene is a simple cyclic organic compound which is found naturally in the environment at low concentrations. Benzene occurs naturally in crude oil and as a consequence is a constituent of petrol. It is also formed during incomplete combustion of fossil fuels (petroleum products, coal, and to a lesser extent, wood). Also, it is a commercially important intermediate in the manufacture of many chemicals. ${ }^{1}$

In the past, benzene was widely used as a solvent, mainly in industrial paints, paint removers, adhesives, degreasing agents, denatured alcohol, rubber cements, and arts and crafts supplies. ${ }^{23}$ The imposition of increasingly lower occupational exposure limits and more stringent legislation has led to a reduction in these uses, with, currently, only $0.74 \%$ of benzene being used as a solvent in the United Kingdom, mainly as a laboratory reagent. ${ }^{3}$ There is a wide range of sources of potential very low concentrations of benzene in homes. For example, building materials and certain furnishing materials may contain residual concentrations of benzene. ${ }^{4}$ Other potential sources include environmental tobacco smoke, photocopier and laser printed paper, particle board furniture, floor adhesives, paints, wood panelling, caulking, and paint remover. $^{5}$

Emissions to air increased significantly in the period 1960-90 as a consequence of the rapid increase in vehicle numbers. During 1995, an estimated 35 kilotonnes of benzene were emitted to the United Kingdom environment. Some $70 \%$ of emissions are currently derived from road transport, mainly from petrol ${ }^{6}$; the most important sources include evaporative losses, refuelling emissions, and combustion of petrol.

The aim of this paper is to give an overview of the available data from the United Kingdom on environmental exposure to benzene from all sources in the general population, to summarise the known health effects, and to use this information to evaluate any potential risk to human health. The paper summarises an extensive report produced by the Institute for Environment and Health.?

\section{Human health effects due to exposure to benzene}

Numerous reviews over the years have described and evaluated adverse health effects associated with exposure to benzene. ${ }^{28-13}$ However, all of these effects were associated with occupational exposures which involve much higher benzene concentrations than are encountered in the general environment. Most occupational exposures are presented as 8 hour time weighted averages (TWAs), and exposures outside the working day are not considered. Furthermore, few of the occupational studies include exposure data for women or for people over the age of 65 years. Studies in children are scarce. Several ecological studies have been conducted to examine adverse health effects associated with point sources from chemical plants. ${ }^{14-17}$ Other studies have examined the association between car ownership, petrol combustion, and motor vehicle exhaust and leukaemia. ${ }^{18}$ Exposure of fathers to benzene and other solvents before conception and postnatally has been associated with increased risk of childhood leukaemia. ${ }^{19-21}$ However, none of these studies had quantitative estimates of benzene.

A summary of the health effects and estimated lowest observed adverse effect levels (LOAELs) for exposure to benzene are presented in table 1.

Acute toxic effects have usually been related to poor working conditions, accidents, or misuse and abuse of benzene. Inhalation of benzene produces acute toxic effects on the central nervous system in humans, which clear rapidly once exposure ends. Inhalation of 800$1600 \mathrm{mg} / \mathrm{m}^{3}$ produces vertigo, drowsiness, headache, and nausea (table 1), whereas higher concentrations of $4800 \mathrm{mg} / \mathrm{m}^{3}$ cause euphoria followed by giddiness, headache, nausea, staggered gait, and with continued exposure, unconsciousness. ${ }^{22}$ Short term exposures to $9600 \mathrm{mg} / \mathrm{m}^{3}$ can be tolerated for $0.5-1.0$ hours. However, exposure to massive concentrations of $64000 \mathrm{mg} / \mathrm{m}^{3}$ or higher can be fatal within 5-10 minutes (table 1 ).

Table 1 Lowest observed adverse effect levels (LOAELs) in humans occupationally exposed to benzene

\begin{tabular}{|c|c|c|c|c|}
\hline Effect & Description & Exposure & $L O A E L$ & Reference \\
\hline \multicolumn{5}{|l|}{ Acute toxicity: } \\
\hline Death & & Minutes & $64000 \mathrm{mg} / \mathrm{m}^{3}$ & Thienes and Haley $(1972)^{82}$ \\
\hline Death $\left(\right.$ oral $\left.{ }^{\star}\right)$ & & & $10 \mathrm{ml}(8.8 \mathrm{~g})$ & Thienes and Haley $(1972)^{82}$ \\
\hline CNS & Vertigo, drowsiness, headache, nausea & Hours & $800 \mathrm{mg} / \mathrm{m}^{3}$ & Clayton and Clayton $(1994)^{22}$ \\
\hline \multicolumn{5}{|l|}{ Chronic toxicity: } \\
\hline \multirow[t]{5}{*}{ Haematological } & Aplastic anaemia, pancytopenia & Years & $320 \mathrm{mg} / \mathrm{m}^{3}$ & Yin et al $(1987)^{83}$ \\
\hline & Myelodysplastic syndrome & & & $\begin{array}{l}\text { Greenberg et al }(1939)^{84} \\
\text { Aksoy et al }(1972)^{85}\end{array}$ \\
\hline & Cytopenia & Years & $96-112 \mathrm{mg} / \mathrm{m}^{3}$ & Fishbeck et al $(1978)^{23}$ \\
\hline & & & & Kipen et al $(1989)^{24}$ \\
\hline & & & & Rothman et al $(1996)^{25}$ \\
\hline \multirow[t]{2}{*}{ Mutagenic } & Chromosomal aberrations & Years & $64-319 \mathrm{mg} / \mathrm{m}^{3}$ & EBS $(1996)^{13}$ \\
\hline & Adduct formation & Years & $40-200 \mathrm{mg} / \mathrm{m}^{3}$ & Liu et al $(1996)^{26}$ \\
\hline Carcinogenic & ANLL & Years & $32-80 \mathrm{mg} / \mathrm{m}^{3}$ & Schnatter et al $(1996)^{48}$ \\
\hline
\end{tabular}

ANLL=acute non-lymphocytic leukaemia; $\mathrm{CNS}=$ central nervous system

*Only effect after oral consumption, all others resulting from inhalation. 
Excessive repeated exposure to benzene $\left(>320 \mathrm{mg} / \mathrm{m}^{3}\right)$ results in pancytopenia and aplastic anaemia, and is generally associated with a marked decrease in the number of cells in the bone marrow, resulting in severe clinical manifestations including immunosuppression and myelodysplastic syndrome. Lower repeated exposure to benzenes $\left(<96 \mathrm{mg} / \mathrm{m}^{3}\right)$ results in cytopenia. Affected people may display a decrease in white blood cells potentially resulting in death due to infection, a decrease in platelet count potentially resulting in death due to haemorrhage, or a decrease in red blood cell count. ${ }^{23-25}$

Benzene is a known clastogen, causing chromosomal aberrations in vitro. The available data weakly suggest that prolonged exposure to long term mean concentrations of $>64 \mathrm{mg} / \mathrm{m}^{3}$ benzene may be associated with chromosomal aberrations. ${ }^{13}$ Other reported indicators of genetic damage are sister chromatid exchanges, DNA cross linking, DNA adduct formation, and DNA repair. A study by Liu $e t a l^{26}$ found that both medium $\left(40-200 \mathrm{mg} / \mathrm{m}^{3}\right)$ and high $\left(>200 \mathrm{mg} / \mathrm{m}^{3}\right)$ concentrations of benzene resulted in significantly increased concentrations of the oxidative DNA adduct 8-hydroxydeoxyguanosine in workers at a shoe factory compared with a control group of university staff.

Benzene has long been known to be a human carcinogen, with the strongest evidence linking it with lymphohaematopoietic cancers, particularly acute non-lymphocytic leukaemia. Most of the evidence derives from industrial studies of workers exposed to benzene, often as a constituent of a complex mixture. These include the shoemaking, printing, petrochemical, chemical, coke production, and rubber manufacturing industries. ${ }^{27-35}$ Many of the populations in these studies were exposed to benzene concentrations that were extremely high compared with concentrations experienced in these industries today.

There have been a few cohort and nested case-control studies that have estimated exposure information for each worker. Based on these studies, attempts have been made to develop dose-response relations with cumulative exposure - that is, assuming a symmetric contribution of concentration and duration of exposure. The cohort that has been most often used in risk assessment is the Pliofilm cohort, which included workers from three factories manufacturing rubber film in the United States. A wide range of exposures was encountered, with relatively few other chemicals involved. There have been several publications from this cohort giving mortality results ${ }^{31}$ 36-39 and risk assessments with different methods of estimating exposure and different mathematical models. ${ }^{31} 40-48$

The most recent follow up ${ }^{49}$ reported 15 deaths from leukaemia, and estimated risks from three separate sets of exposure estimates. $^{37445}$ The lowest exposure estimates were made by Rinsky et $a l^{77}$ and the highest by Paustenbach et $a l^{45}$. Based on the exposure estimates of Crump and Allen ${ }^{44}$ and Rinsky et $a b^{\beta 7}$ excess risk for all leukaemia occurred at
$160 \mathrm{mg} / \mathrm{m}^{3}$ years, whereas based on the estimates of Paustenbach et $a l^{45}$ no risk occurred until a cumulative exposure of more than $1600 \mathrm{mg} / \mathrm{m}^{3}$.years.

Four other cohort studies have measured exposure to benzenes for all their study subjects. ${ }^{50-53}$ Bond et $a l,^{50}$ in a follow up of a study by Ott et $a P^{4}$ of 956 Dow chemical workers, found three deaths from leukaemia compared with 1.9 expected. Wong and Ott et $a P^{3-55}$ followed up 7676 chemical workers, 3536 of whom were continuously exposed to benzene. Six deaths from leukaemia were reported in the exposed group compared with 4.5 expected. An update of a subgroup of this population has been reported by Ireland et al..$^{52}$ There were three cases of leukaemia found at exposures of $6 \mathrm{ppm}\left(19.2 \mathrm{mg} / \mathrm{m}^{3}\right)$ or greater compared with 0.65 expected. Hayes et al reported ${ }^{51}$ mortality results from a very large cohort of Chinese workers exposed between 1972 and 1987 in a variety of occupations. Excess risks were found for all leukaemias at all concentrations of exposure and above $40 \mathrm{ppm}$ for acute nonlymphocytic leukaemia.

Two nested case-control studies have also been carried out on petroleum distribution workers ${ }^{56}{ }^{57}$ in which the method of retrospective quantitative estimation of exposures was essentially the same. No excess risk was found in any category of exposure in the study by Schnatter et al. ${ }^{57}$ Of the 90 cases of leukaemia identified in the study by Rushton and Romaniuk, ${ }^{56} 31$ were acute myeloid and monocytic leukaemia (AMML). Risk from AMML did not increase with cumulative exposure analysed as a continuous variable. When categorised into discrete ranges an odds ratio of 2.8 was found $(95 \%$ confidence interval $(95 \% \mathrm{CI})$ 0.8 to 9.4 ) for a cumulative exposure of $4.5-45$ ppm.years (14.4-144 $\mathrm{mg} / \mathrm{m}^{3}$.years) compared with $<0.45 \mathrm{ppm}$.years $\left(<1.44 \mathrm{mg} / \mathrm{m}^{3}\right.$.years $)$.

A pooled analysis of the data from four studies $^{31485256}$ has been carried out ${ }^{13}$ with several models. No dose-response pattern was found at concentrations of exposure below $1 \mathrm{ppm}$ $\left(3.2 \mu \mathrm{g} / \mathrm{m}^{3}\right)$. However, a cumulative exposure relation with acute non-lymphocytic leukaemia was suggested when concentrations were above about $20-50 \mathrm{ppm}\left(64-164 \mu \mathrm{g} / \mathrm{m}^{3}\right)$.

\section{Assessment of environmental exposure to benzene}

Benzene has been reported in various matrices including air, fresh water and marine water, sediment, soil, foodstuffs, and organisms. ${ }^{1}$ As benzene is primarily found in the atmosphere and human exposure is mainly through inhalation (95\% of daily intake ${ }^{39}$ ) most monitoring programmes have concentrated on measuring concentrations in air.

\section{AMBIENT AIR CONCENTRATIONS}

Benzene has been routinely monitored in ambient outdoor air in the United Kingdom since 1991 as part of the automatic hydrocarbon monitoring network of the Department of the Environment, Transport, and the Regions. ${ }^{58}$ Monitoring has also been carried out with passive monitoring networks. Tables 2 and 
Table 2 United Kingdom concentrations of benzene in outdoor air $\left(\mu \mathrm{g} / \mathrm{m}^{3}\right)$ for 1995 from the automatic hydrocarbon monitoring network*

\begin{tabular}{llllll}
\hline Location & Site & Start date & $\begin{array}{l}\text { 1995 Mean } \\
\text { concentration }\end{array}$ & $\begin{array}{l}\text { Maximum hourly } \\
\text { concentration }\end{array}$ & Data capture (\%) \\
\hline Middlesborough & Urban industrial & Jan 1993 & 3.5 & 139 & 95 \\
London & Roadside & Feb 1993 & 5.4 & 60 & 91 \\
London & Suburban & Mar 1993 & 3.2 & 49 & 91 \\
Belfast & Urban background & Aug 1993 & 2.9 & 109 & 95 \\
Birmingham & Urban background & Aug 1993 & 3.2 & 108 & 95 \\
Edinburgh & Urban background & Aug 1993 & 2.2 & 36 & 86 \\
Cardiff & Urban background & Nov 1993 & 3.8 & 78 & 93 \\
Bristol & Urban background & May 1994 & 3.8 & 100 & 94 \\
Harwell & Rural & Jan 1995 & 1.3 & 15.4 & 28 \\
Leeds & Urban background & Jan 1995 & 3.2 & 76 & 10 \\
Southampton & Urban centre & Sep 1995 & $8.0 \dagger$ & 39 & \\
Liverpool & Urban background & Nov 1995 & $5.1 \ddagger$ & 34 & \\
\hline
\end{tabular}

Values reported as ppb by the AEA. ${ }^{6}$

${ }^{\star}$ Each monitoring station uses instruments which sample and analyse the ambient air continuously to provide levels of resolution. † Mean concentration is a 4 monthly average as sampling was only conducted from September to December 1995.

$¥$ Mean concentration is a 1 monthly average as sampling was only conducted during December 1995 .

Concentrations for $\dagger$ and $\ddagger$ sites were not representative of the year as a whole as monitoring was not conducted for a whole year.

3 summarise recent United Kingdom data from these systems. Annual mean concentrations at urban sites (including suburban, city centre, and urban industrial) were in the range of $2.2-8.0 \mu \mathrm{g} / \mathrm{m}^{3}$. Data from a rural site showed a mean annual concentration of $1.3 \mu \mathrm{g} / \mathrm{m}^{3}$, which is about $30 \%-35 \%$ of the current concentrations measured at most urban backgrounds. ${ }^{58}$ The running annual mean standard for benzene of $16 \mu \mathrm{g} / \mathrm{m}^{3}$ ( $5 \mathrm{ppb}$ ) recommended by the United Kingdom Expert Panel on Air Quality Standards (EPAQS) was not exceeded, although the EPAQS recommended target concentration for benzene of $3.2 \mu \mathrm{g} / \mathrm{m}^{3}$ (1 ppb) was exceeded at several urban sites. ${ }^{59}$

Similar results have also been found in the London area where much benzene monitoring has been carried out with diffusion tubes. ${ }^{60}$ Benzene concentrations of as much as 118 $\mu \mathrm{g} / \mathrm{m}^{3}$ have been reported at roadside sites close to the kerbside. Mean benzene concentrations at sites within $20 \mathrm{~m}$ of busy roads seem to cover the range $10-45 \mu \mathrm{g} / \mathrm{m}^{3}$. These concentrations are consistent with mean concentrations of $30-37 \mu \mathrm{g} / \mathrm{m}^{3}$ at the kerbside adjacent to roads with heavy traffic, estimated from measurements made at the Cromwell Road in London. ${ }^{60}$

There is a marked seasonal variation in outdoor air concentrations of benzene; in the winter they are about 1.5-3 times higher than during the summer, ${ }^{58}{ }^{61}$ possibly owing to the higher prevalence of cold still weather conditions at this time of year. Typical average concentrations in the Avon area for the period June
1991 to May 1992, for example, were $3 \mu \mathrm{g} / \mathrm{m}^{3}$ during the spring and summer and 5 and 8 $\mu \mathrm{g} / \mathrm{m}^{3}$ during the autumn and winter months, respectively. ${ }^{61}$

\section{INDOOR AIR CONCENTRATIONS}

The Building Research Establishment (BRE) determined the concentrations of specific pollutants, including benzene, in a sample of 174 households of participants of the Avon longitudinal study of pregnancy and childhood in the Avon area. ${ }^{62}$ The mean indoor concentration was $8 \mu \mathrm{g} / \mathrm{m}^{3}$ compared with an outdoor mean of $5 \mu \mathrm{g} / \mathrm{m}^{3}$. Higher concentrations of benzene in indoor air were associated with the presence of an attached garage, with the presence of a car kept in the garage being shown to result in an $80 \%$ increase in indoor air concentrations in the home. ${ }^{61}$

The BRE indoor environment study also reported a seasonal variation in indoor air concentrations which was due to the higher concentrations in the outdoor air which infiltrated the building, and the greater influence of indoor sources during winter compared with summer months, probably due to the lower rates of ventilation. ${ }^{61}$

Cigarette smoke has been found to contribute significantly to the concentrations of benzene reported in indoor air. The BRE study reported a significant increase in mean benzene concentrations in the living rooms of homes with one or more occupants who smoked compared with a non-smoking environment (9.6 $\mu \mathrm{g} / \mathrm{m}^{3}$ compared with $\left.7.2 \mu \mathrm{g} / \mathrm{m}^{3}\right) .{ }^{61}$ Another

Table 3 United Kingdom concentrations of benzene in outdoor air $\left(\mu \mathrm{g} / \mathrm{m}^{3}\right)$ from passive monitoring networks

\begin{tabular}{lllll}
\hline Location & Sites $(n)$ & Concentration & Comment & Reference \\
\hline Urban, London & 1 & $3.2-43.5^{\star}$ & Monthly average & EPAQS $(1994)^{59}$ \\
Outdoor, general $\dagger$ & 59 & $1.6-7.04^{\star}$ & Mean ranges over 6 months & Downing et al $(1994)^{86}$ \\
Outdoor, Avon & 13 & 5 & Annual mean & Brown and Crump $(1996)^{62}$ \\
Roadside (<20 m) & $\mathrm{NR}$ & $10-45^{\star}$ & Averaging time not reported & DoE $(1997)^{60}$ \\
Semirural, Manchester & 2 & $0.86-1.95^{\star} \ddagger$ & Annual running mean & \\
Urban, Manchester & 3 & $1.28-3.14^{\star} \ddagger$ & Annual running mean & \\
Road side, Manchester & 2 & $1.92-6.85^{\star} \ddagger$ & Annual running mean & \\
\hline
\end{tabular}

$\mathrm{NR}=$ number of sites not reported.

*Values reported as ppb.

†This survey was conducted over a 6 month period in 1992 and measured various hydrocarbons at 59 sites with diffusion tubes. ¥Based on data supplied by Environmental Health Division, Technical Services Department, Manchester City Council, Town Hall, Manchester M60 2JT. Benzene monitoring has been conducted by Manchester City Council at seven locations since 1994. Data presented here are for the period January 1995-July 1997. The methodology involves passive sampling to obtain 2-weekly as well as annual running averages.

$§$ Passive sampling with diffusion tubes. 
study in the United Kingdom, conducted by Leung and Harrison, ${ }^{63}$ reported higher daily exposures to benzene (active sampling over 12 hours during the day) for current smokers $\left(23.0 \mu \mathrm{g} / \mathrm{m}^{3}\right)$ than for non-smokers (11.52 $\mu \mathrm{g} / \mathrm{m}^{3}$ ). Regular smoking (when smoking occurred every hour throughout the sampling period) led to increased concentrations of up to a maximum of $57 \mu \mathrm{g} / \mathrm{m}^{3}$.

REFUELLING AND CONCENTRATIONS IN VEHICLES Refuelling at petrol stations and exposure in vehicles have been shown to contribute to increased exposure to benzene. During refuelling, petrol station exposure varies according to the benzene content of fuel (usually, about $2 \%$ ), the presence or absence of vapour control devices, and the amount of time spent at the stations. A detailed study has been conducted in Italy to determine the exposure of service station employees to benzene. (The results of the study, evaluation of exposure to benzene of employees and customers in filling stations of the AgipPetroli sector, were presented to a meeting held in Rome, Italy in February 1993. The data are available from AgipPetroli, Sede Centrale, Via Laurentina 449, 00142 Rome, Italy.) A total of 72 service stations were monitored throughout Italy covering motorway, suburban, and urban areas. The highest benzene concentrations were reported in the breathing zone of petrol station attendants, who were exposed to an average concentration of $482 \mu \mathrm{g} / \mathrm{m}^{3}$. Fifty two per cent were exposed to an average of $320 \mu \mathrm{g} / \mathrm{m}^{3}$, while $8 \%$ received maximum exposure concentrations in the region of $2000-3200 \mu \mathrm{g} / \mathrm{m}^{3}$. Exposure varied widely, not only between different petrol stations, but also for the same petrol attendants at different times. Exposure to benzene was found to be related to the car type and pressure within the petrol tank and the ambient air.

The AgipPetroli study also showed that a single refuelling operation lasted about 1 minute, and that the mean air concentration to which the petrol attendant was exposed was $3709 \mu \mathrm{g} / \mathrm{m}^{3}$, most of the benzene (88\%) being emitted while supplying fuel to the vehicle. The introduction of vapour recovery systems was estimated to reduce the exposure of benzene emissions to $930 \mu \mathrm{g} / \mathrm{m}^{3}$. An industrial hygiene subgroup of the Oil Companies' European Organisation for Environment, Health and Safety (CONCAWE) collated and summarised data from member companies on short term exposures (2-5 minutes) in the breathing zone of five service station attendants for the period 1986-92. ${ }^{64}$ The mean air concentration was $2144 \mu \mathrm{g} / \mathrm{m}^{3}$ with a range of $160-5200 \mu \mathrm{g} / \mathrm{m}^{3}$ which seems to be in general agreement with the values reported for petrol attendants in the Italian study. This information, particularly the peak exposure during refuelling, can be used to derive exposure patterns for motorists in the United Kingdom who tend to self serve in filling stations.

Benzene found in the air inside vehicles is largely derived from engine exhaust emissions or evaporative losses, and varies in concentration according to the vehicle type and age, the fuel used, traffic variables, such as density and speed, and ventilation - that is, whether windows are open and ventilation fans or heaters are switched on. ${ }^{65}$ Older vehicles tend to have slightly higher concentrations of vehicular pollutants than new vehicles. Slower average speeds, due to increased traffic, also tend to raise benzene concentrations inside the vehicle. At faster speeds there will be greater air turbulence, thereby diluting pollutant concentrations. ${ }^{65}$ Similarly, concentrations seem to be lower with windows closed and vents opened and with windows closed and air conditioning on. ${ }^{65} \mathrm{~A}$ mean in vehicle concentration of 55 $\mu \mathrm{g} / \mathrm{m}^{3}$ was reported for three BRE employees compared with an outdoor background concentration of $5 \mu \mathrm{g} / \mathrm{m}^{3}$. ${ }^{66}$

\section{CONCENTRATIONS OF BENZENE FROM OTHER}

SOURCES OF EXPOSURE

Benzene is not found in notable amounts in water, food, or consumer products. Freshwater, groundwater, and abstracted water concentrations generally have a mean concentration of benzene (range) of $0.64 \quad(<0.1-35) \mu \mathrm{g} / 1$, although in most samples $(72 \%-100 \%)$, concentrations are below the detection limit. ${ }^{67}$ Higher benzene concentrations of up to 12.5 $\mathrm{mg} / 1$ may be detected at contaminated sites.

As part of the total diet study, the Ministry of Agriculture, Fisheries and Food (MAFF) has measured benzene concentrations in foodstuffs in the United Kingdom. Mean benzene concentrations were $2.03 \mu \mathrm{g} / \mathrm{kg}$ of total food, with benzene being detected in most samples of carcass meat, offal, meat products, poultry, fish, and nuts, but not detected in most other food groups. ${ }^{68}$

As benzene is no longer permitted in products marketed to the general public, with the exception of petrol, any exposure from trace amounts in consumer products remaining in the home will be accounted for in measurements of indoor air.

RESULTS FROM PERSONAL AIRBORNE EXPOSURE MONITORING

The exposure of individual people to pollutants is dependent upon the time spent in a particular microenvironment and the concentration of the pollutant in that microenvironment. As people spend most of their time indoors, their exposure to benzene is strongly influenced by the concentrations of this compound in the indoor environment. ${ }^{66}$ Exposure can also be enhanced by personal activities which result in higher concentrations in the breathing zone than in the general indoor environment-for example, through smoking.

The inhaled dose of benzene from cigarettes has been reported to be in the range 16-75 $\mu \mathrm{g} /$ cigarette. $^{69}$ Assuming an average of 40 $\mu \mathrm{g} /$ cigarette and assuming that $50 \%$ of inhaled benzene is absorbed or retained in the body, smoking 20 cigarettes/day would result in an inhaled amount of $800 \mu \mathrm{g} /$ day and a retained dose of $400 \mu \mathrm{g} /$ day.

With passive diffusion samplers, Mann et al $(1997)^{66}$ monitored the exposure of four BRE employees (all non-smokers) over a period of 
12-30 months. The results, summarised in table 4 , showed that mean personal exposure ranged from $7.3-11.0 \mu \mathrm{g} / \mathrm{m}^{3}$. Highest exposure to benzenes were found in the garage, inside vehicles, and while riding a bicycle. Concentrations were lowest in the office and outside. With time activity data and concentrations of benzene in air in the different microenvironments, Mann et al ${ }^{66}$ estimated that for individual people living in a non-smoking environment, the main exposure to benzene was through indoor air, owing to the high proportion of time spent in this microenvironment. Although only a short time $(5 \%-8 \%$ of the day) was spent in a vehicle, exposure during transport was also relatively high, and resulted in $34 \%-44 \%$ of the total daily exposure to benzene.

In a larger study conducted by Leung and Harrison $^{63}$ active air sampling was used to monitor the personal exposure of 50 volunteers. In vehicle concentrations generally exceeded those measured at background outdoor locations (table 4) as did some of the indoor air concentrations. Personal exposures calculated indirectly from activity diaries and microenvironment measures (some of which are summarised in table 4) correlated well with those obtained directly from personal samplers. Personal exposures in the daytime (both urban and rural) were higher than at night (urban and rural). Increased exposures were experienced during refuelling and driving, especially in areas where dispersion was limited - such as in road tunnels and multistorey car parks. Exposure was further increased in volunteers who commuted during rush hours or travelled in congested traffic.

\section{Estimation of typical daily intakes of benzene}

Broadly, there are two ways of calculating a person's exposure to a substance. Firstly, individual exposure can be measured by personal monitoring over a typical period as they move between microenvironments. Secondly, typical concentrations in a relevant number of microenvironments can be measured and then be related to the time activity pattern of various subpopulations in each of those microenvironments.

The daily intake of a compound is the amount directly taken into the body by inhalation and ingestion of food and water. A summary of typical concentrations and doses of benzene for the key environment compartments is presented in table 5 on the basis of the information in these sections. As the contribution that food and water ingestion make to overall daily intake of benzene is likely to be very small, only exposure through inhalation has been considered. The value of $4 \mu \mathrm{g} / \mathrm{m}^{3}$ for outdoor urban air is the mean of the figures for the nine urban sites presented in table 2 and the roadside value is derived from the mean for the London study. ${ }^{60}$ The figures for refuelling were taken from the study by AgipPetroli (1995). Based on data presented for concentrations in vehicles, a value of 11 times the average urban concentration of $4 \mu \mathrm{g} / \mathrm{m}^{3}$ is thought to be representative of typical exposure while driving and therefore typical in vehicle concentration can be assumed to be $44 \mu \mathrm{g} / \mathrm{m}^{3}$. The figures for indoor concentrations in homes were taken from Crump. ${ }^{61}$

The daily exposure through inhalation can be calculated by multiplying the daily amount of air inhaled by the benzene concentration measured in each microenvironment - for example, concentration in the work place, in vehicles, home, or outdoors - by the fraction of time spent in that microenvironment, estimated from time activity surveys. These, in conjunction with appropriate inhalation and absorption rates, can then be used to estimate exposure to benzene for various subpopulations of the non-occupationally exposed general population.

TIME-ACTIVITY DATA

In northern European countries, people spend a large proportion of their time indoors (about $90 \%-95 \%$ ), and much of this time is in the home. ${ }^{66}$ Although no in depth studies have been conducted in the United Kingdom to determine time-activity patterns for the general

Table 4 Benzene concentrations $\left(\mu \mathrm{g} / \mathrm{m}^{3}\right)$ measured by personal and fixed site monitors for two United Kingdom studies

\begin{tabular}{|c|c|c|c|c|c|c|}
\hline \multirow[b]{2}{*}{ Study location } & \multicolumn{2}{|l|}{$B R E$ study ${ }^{\star}$} & \multicolumn{4}{|c|}{ Birmingham studyt‡ } \\
\hline & Employees (n) & $\begin{array}{l}\text { Range of } \\
\text { means }\end{array}$ & Observations ( $n$ ) & Mean & $S D$ & Range \\
\hline Living room $\$ & 4 & $5.5-7.2$ & 15 & 11.52 & 2.24 & - \\
\hline Main bedroom & 4 & $8.5-17.8$ & - & - & - & - \\
\hline Smoky pub & - & - & 16 & 79 & 21.12 & - \\
\hline Outside & 3 & $2.9-7.3$ & 15 & 14.08 & 2.24 & - \\
\hline Pedestrian area & - & - & 15 & 18.24 & 2.88 & - \\
\hline In vehicle & 3 & $19.0-80.3$ & 52 & 41.3 & 34.9 & - \\
\hline On bicycle & 1 & 16.1 & 15 & 12.48 & 4.16 & - \\
\hline Office & 4 & $3.5-5.0$ & - & - & - & - \\
\hline Refuelling & - & - & 15 & 190 & 155 & - \\
\hline Garage & 1 & 144.7 & - & - & - & - \\
\hline \multicolumn{7}{|l|}{ Personal exposure: } \\
\hline Annual mean & 4 & $7.3-11.0$ & - & - & - & - \\
\hline $12 \mathrm{~h}$ daytime exposure & - & - & 50 & 12.2 & - & $0.74-283$ \\
\hline $12 \mathrm{~h}$ night time exposure & - & - & - & 6.2 & - & $1.95-18$ \\
\hline
\end{tabular}

^Data from Mann et $a l^{66}$; sampling at fixed locations was for consecutive 28 day exposure periods.

†Data from Leung and Harrison ${ }^{63}$; microenvironment sampling periods were between 10 and 30 minutes. Outside refers to Birmingham city centre.

¥Values reported as ppb in original papers.

§Non-smoking house. 
Table 5 Summary of typical environmental concentrations for the United Kingdom

\begin{tabular}{|c|c|c|}
\hline Media & Concentration & Comment \\
\hline \multicolumn{3}{|l|}{ Air: } \\
\hline Outdoors, rural & $1.3 \mu \mathrm{g} / \mathrm{m}^{3}$ & \\
\hline Outdoors, urban & $4 \mu \mathrm{g} / \mathrm{m}^{3}$ & \\
\hline Roadside & $33 \mu \mathrm{g} / \mathrm{m}^{3}$ & Adjacent to heavy traffic road \\
\hline During refuelling & $3700 \mu \mathrm{g} / \mathrm{m}^{3}$ & No evaporative emission control installed \\
\hline During refuelling & $930 \mu \mathrm{g} / \mathrm{m}^{3}$ & Evaporative emission control installed \\
\hline In vehicle ${ }^{\star}$ & $44 \mu \mathrm{g} / \mathrm{m}^{3}$ & 11 Times concentrations of background urban sites \\
\hline Indoors, rural no smokers $†$ & $5 \mu \mathrm{g} / \mathrm{m}^{3}$ & \\
\hline Indoors, urban no smokerst & $7 \mu \mathrm{g} / \mathrm{m}^{3}$ & \\
\hline Indoors, 1 or more smokerst & $10 \mu \mathrm{g} / \mathrm{m}^{3}$ & \\
\hline Active smoking & $800(400) \mu \mathrm{g} /$ day & $\begin{array}{l}\text { Average daily exposure (and retained dose) assuming that } 20 \\
\text { cigarettes are smoked a day, each containing } 40 \mu \mathrm{g} \text { of benzene and } \\
\text { that } 50 \% \text { of inhaled benzene is absorbed }\end{array}$ \\
\hline \multicolumn{3}{|r|}{ tene } \\
\hline Drinking water & $0.64 \mu \mathrm{g} / 1$ & \\
\hline Foodstuffs & $2.0 \mu \mathrm{g} / \mathrm{kg}$ & Average concentrations in food \\
\hline Soil & Trace amounts & \\
\hline Consumer products & Trace amounts & \\
\hline Dermal & Trace amounts & \\
\hline
\end{tabular}

${ }^{\star}$ Concentrations are assumed to be similar while using public and private transport as no information is available for concentrations in buses. If the main form of transport is by rail, this value is likely to over estimate actual concentrations; Leung and Harrison ${ }^{63}$ have shown levels in trains to be lower than in vehicle concentrations.

tOwing to lack of monitoring data in other indoor areas-for example, offices, schools, etc - it is assumed that concentrations in these areas are similar to those reported in the home.

population, there are a few studies that report this type of information for specific population groups. For the purpose of this assessment, time activity has been subdivided into (a) $91 \%$ spent indoors (home, office, or elsewhere), (b) $5 \%$ spent in transport (public or private), $(c) 2$ minutes a week spent refuelling (not children or infants), and (d) $4 \%$ spent outdoors. ${ }^{7}$ For the purpose of this paper it has been assumed that children and infants will not be exposed to benzene from refuelling. Although they are unlikely to be adjacent to the petrol pump or petrol tank during refuelling, it is possible that exposure inside the vehicle might increase during this procedure. However, no reliable data exist with which to estimate this. For smokers, a daily dose of $400 \mu \mathrm{g} /$ day from cigarettes has been assumed.

INHALATION AND ABSORPTION RATES

An average inhalation rate of $20 \mathrm{~m}^{3}$ air/day and an absorption rate of $50 \%$ has been assumed for estimating the human absorbed dose of benzene through inhalation. ${ }^{7}$ This inhalation rate value is widely used to determine the inhaled dose for a given air pollutant for adults. Children have much lower inhalation rates; Layton $^{78}$ reported average inhalation rates for

Table 6 Estimated absorbed daily doses of benzene ( $\mu \mathrm{g} /$ day) for members of the general public under different exposure scenarios

\begin{tabular}{|c|c|c|c|c|c|}
\hline Activity & $\begin{array}{l}\text { Rural } \\
\text { non-smoker (a) }\end{array}$ & $\begin{array}{l}\text { Urban } \\
\text { non-smoker (b) }\end{array}$ & $\begin{array}{l}\text { Urban passive } \\
\text { smoker (c) }\end{array}$ & $\begin{array}{l}\text { Urban } \\
\text { smoker (d) }\end{array}$ & $\begin{array}{l}\text { Extreme } \\
\text { case }(e)\end{array}$ \\
\hline Indoors & 45.5 & 63.7 & 91 & 91 & 58 \\
\hline In vehicle & 22 & 22 & 22 & 22 & 22 \\
\hline Refuelling ${ }^{\star}$ & $1.9-7.4$ & $1.9-7.4$ & $1.9-7.4$ & $1.9-7.4$ & $1.9-7.4$ \\
\hline Outdoors, pleasure & 0.5 & 1.6 & 1.6 & 1.6 & 1.6 \\
\hline Outdoors, work† & - & - & - & - & 330 \\
\hline Smoking & - & - & - & 400 & 400 \\
\hline Total daily dose & $70-75$ & $89-95$ & $116-122$ & $516-522$ & $814-819$ \\
\hline
\end{tabular}

* The lower of the reported range refers to whether vapour recovery equipment has been fitted in filling necks and petrol pump nozzles. As these are still not required by United Kingdom or European Union legislation, the higher value of this range will reflect current exposure more accurately and therefore this value is used for evaluating benzene exposure to the general United Kingdom population. As the Department of the Environment, Transport and the Regions is preparing a consultation paper for a scheme to implement controls to reduce emissions from this source, there should be a gradual reduction of exposure to benzene from this source (down to an estimated daily absorbed dose of $1.5 \mu \mathrm{g}$ ) over the next few years.

†Breathing rate for heavy activity is $2.5 \mathrm{~m}^{3} / \mathrm{h}\left(\right.$ Layton $\left.^{78}\right)$. infants $(<1$ year old) and children (aged $1-10$ years) of 4.5 and $8.6 \mathrm{~m}^{3}$ per day, respectively.

\section{Human exposure estimates with different exposure scenarios}

Using these time-activity patterns and inhalation and absorption rates, in conjunction with measured benzene air concentrations for each microenvironment, absorbed daily doses for the United Kingdom general adult population have been estimated for five scenarios (table 6).

(a) Non-smoker who lives in a rural environment.

(b) Non-smoker who lives in an urban environment.

(c) Non-smoker who lives in an urban environment in a house where at least one member of the family smokes.

(d) Smoker who lives in an urban environment.

(e) Smoker who spends 8 hours/day actively working close to heavy traffic-for example, road workers on a busy city-centre road.

The absorbed daily dose for a rural nonsmoker, although indoors is calculated, for example, by multiplying the typical indoors concentration for a rural non-smoker from table $5\left(5 \mu \mathrm{g} / \mathrm{m}^{3}\right)$, the proportion of time spent indoors (0.91), the mean inhalation rate $(20$ $\mathrm{m}^{3}$ ), and the absorption rate $(0.50)$ to give 45.5 $\mu \mathrm{g} /$ day. Similar calculations have been made for the other three time activities for this scenario-namely, time spent in vehicles, refuelling, and outdoors - and these four calculations have been summed to give the total daily dose for a rural non-smoker of 70-75 $\mu \mathrm{g} /$ day .

Thus, the estimated mean absorbed doses of benzene to which the general population are exposed through air in non-smoking environments are estimated to be in the ranges $70-75$ $\mu \mathrm{g} /$ day and 89-95 $\mu \mathrm{g} /$ day, for rural and urban residents, respectively (table 6 ). Rural residents are exposed to lower concentrations owing to the lower indoor air concentrations. Table 6 shows that active smoking can contribute four times the dose obtained from all other sources. 
Table 7 Estimated benzene absorbed daily doses ( $\mu \mathrm{g} /$ day) for infants and children under different exposure scenarios

\begin{tabular}{lllllrr}
\hline Activity & $\begin{array}{l}\text { Rural } \\
\text { infant }(f)\end{array}$ & $\begin{array}{l}\text { Urban } \\
\text { infant }(g)\end{array}$ & $\begin{array}{l}\text { Urban infant } \\
\text { passive smoker }(h)\end{array}$ & $\begin{array}{l}\text { Rural } \\
\text { child }(i)\end{array}$ & $\begin{array}{l}\text { Urban } \\
\text { child (j) }\end{array}$ & $\begin{array}{l}\text { Urban child } \\
\text { passive smoker ( } k \text { ) }\end{array}$ \\
\hline Indoors & 10.2 & 14.3 & 20.5 & 19.6 & 27.4 & 39.1 \\
In vehicle & 5.0 & 5.0 & 5.0 & 9.5 & 9.5 & 9.5 \\
Outdoors, pleasure & 0.1 & 0.4 & 0.4 & 0.2 & 0.7 & 0.7 \\
Total daily dose & 15.3 & 19.7 & 25.9 & 29.3 & 37.6 & 49.3 \\
\hline
\end{tabular}

^Note that because of rounding total daily dose may not add up to last decimal place.

Table 8 Summary of estimated absorbed doses of benzene for adult members of the general public under different exposure scenarios

\begin{tabular}{|c|c|c|c|c|}
\hline & \multirow{2}{*}{$\begin{array}{l}\text { Daily dose } \\
\text { ( } \text { g/day) }\end{array}$} & \multicolumn{2}{|c|}{ Daily intake $\left.(\mu \mathrm{g} / \mathrm{kg} \text { bw/day })^{\star}\right)$} & \multirow{2}{*}{$\begin{array}{l}\text { Equivalent atmosphere } \\
\text { concentrationt }\left(\mu g / \mathrm{m}^{3}\right)\end{array}$} \\
\hline & & Women & Men & \\
\hline Rural non-smoker & 75 & 1.29 & 1.07 & 3.75 \\
\hline Urban non-smoker & 95 & 1.64 & 1.36 & 4.75 \\
\hline Urban passive smoker & 122 & 2.10 & 1.74 & 6.10 \\
\hline Urban smoker & 522 & 9.00 & 7.46 & 26.10 \\
\hline \multicolumn{5}{|l|}{ Urban smoker who works } \\
\hline adjacent to busy road for $8 \mathrm{~h} /$ day & 819 & 14.12 & 11.70 & 41.95 \\
\hline
\end{tabular}

*Values converted from daily doses by assuming that the average United Kingdom woman and man weigh 70 and $58 \mathrm{~kg}$, respectively. ${ }^{7}$

tValues converted from daily doses by assuming that the average person inhales $20 \mathrm{~m}^{3}$ of air per day.

Exposure to benzene will be higher for people who spend a large proportion of their day near city centres and congested roads, especially when involved in high levels of physical activity (as this will increase their inhalation rate and therefore intake of benzene from air). An example of such a situation is presented in scenario $(e)$ where a person who smokes 20 cigarettes/day and works 8 hours/day in an active job-for example, a labourer-adjacent to a busy city centre road, may be exposed to an absorbed dose of $819 \mu \mathrm{g} /$ day (table 6).

Table 7 presents estimates for infants $(<1$ year old) and children (aged 11 years) for similar scenarios:

$(f)$ An infant who lives in a rural environment.

(g) An infant who lives in an urban environment.

(h) An infant who lives in an urban environment in a house where at least one member of the family smokes.

(i) A child who lives in a rural environment.

(j) A child who lives in an urban environment.

(k) A child who lives in an urban environment in a house where at least one member of the family smokes.

Infants and children living in rural areas receive around half the daily absorbed dose of benzene $(15.3 \mu \mathrm{g} /$ day and $29.3 \mu \mathrm{g} /$ day, respectively) of those living in cities $(19.7 \mu \mathrm{g} /$ day and

Table 9 Summary of estimated absorbed doses of benzene for infants and children under different exposure scenarios

\begin{tabular}{llll}
\hline & $\begin{array}{l}\text { Daily dose } \\
(\mu g / \text { day })\end{array}$ & $\begin{array}{l}\text { Daily intake } \\
(\mu g / k g \text { bw/day }\end{array}$ & $\begin{array}{l}\text { Equivalent atmospheric } \\
\text { concentrationt }\left(\mu g / m^{3}\right)\end{array}$ \\
\hline Rural infant & 15.3 & 1.68 & 3.40 \\
Urban infant & 19.7 & 2.16 & 4.38 \\
Urban infant, passive smoker & 25.9 & 2.55 & 5.76 \\
Rural child & 29.3 & 0.71 & 3.37 \\
Urban child & 37.6 & 0.91 & 4.32 \\
Urban child, passive smoker & 49.3 & 1.20 & 5.67
\end{tabular}

*Values converted from daily doses by assuming that the average infant ( $<1$ year old) weighs 9.1 $\mathrm{kg}$ and the average child ( 11 years old) weighs $41.1 \mathrm{~kg}$; there will be a progression in ranges so that on average a 1 year old weighs $11.3 \mathrm{~kg}$, a 5 year old weighs $19.7 \mathrm{~kg}$, an 8 year old weighs $28.1 \mathrm{~kg}$, and so on.

†Values converted from daily doses by assuming that the average infant and child inhales a volume of air of 4.5 and $8.7 \mathrm{~m}^{3} /$ day respectively.
$37.6 \mu \mathrm{g} /$ day). Attention is drawn to the increase in dose received by infants and children through passive smoking.

Tables 8 and 9 present the daily doses $(\mu \mathrm{g} /$ day), from table 6 and 7 , respectively expressed as daily intakes $(\mu \mathrm{g} / \mathrm{kg}$ body weight/ day), and as mean daily inhaled dose-that is, the atmospheric concentration to which a person would have to be exposed every day to achieve the daily dose, the "equivalent atmospheric concentration" $\left(\mu \mathrm{g} / \mathrm{m}^{3}\right)$. The upper point of the ranges for adults have been used. Values were converted from daily doses to daily intakes by assuming that the average infant $(<1$ year old) weighs $9.1 \mathrm{~kg}$, the average child (age 11 years old) weighs $41.1 \mathrm{~kg}$, and the average man and woman weigh 70 and $58 \mathrm{~kg}$, respectively. These may not be representative of the whole United Kingdom population, but have been used to give an estimate of exposures in typical people. Similarly values were converted from daily doses to equivalent atmospheric concentration by assuming that the average infant, child, and adult inhales a volume of air of $4.5,8.7$, and $20 \mathrm{~m}^{3} /$ day, respectively. The atmospheric concentrations are particularly useful estimates, as the limit values, whether environmental or occupational, for substances which are principally encountered as airborne contaminants, are expressed in such units. Thus, risk management procedures, should they be thought necessary at any stage, can use the figures, the typical microenvironment concentrations, time-activity patterns, as well as emission concentrations and make risk reduction recommendations based on real information.

Table 9 shows that infants and children receive a mean daily dose of 15.3-25.9 and $29.3-49.3 \mu \mathrm{g} /$ day, respectively, equivalent to a mean atmospheric concentration of 3.4-5.76 $\mu \mathrm{g} / \mathrm{m}^{3}$ and $3.37-5.67 \mu \mathrm{g} / \mathrm{m}^{3}$. It is worth noting that infants and children exposed to environmental tobacco smoke have concentrations of exposure to benzene comparable with those of an adult passive smoker (table 8). The potential consequences of exposure to benzene 
in infants may be more important than equivalent exposure for children or adults owing to their lower body weight; this is reflected in their higher daily intake (1.68-2.85 $\mu \mathrm{g} / \mathrm{kg} \mathrm{bw/day)} \mathrm{in} \mathrm{comparison} \mathrm{with} \mathrm{children}$ (0.71-1.20 $\mu \mathrm{g} / \mathrm{kg}$ bw/day) or non-smoking adults $(1.07-2.10 \mu \mathrm{g} / \mathrm{kg}$ bw/day). The worst case scenario for exposure to benzene in the general population is that of an urban smoker who works adjacent to a busy road for 8 hours/ day-for example, a maintenance worker. This person's average daily exposure would be about $42 \mu \mathrm{g} / \mathrm{m}^{3}$ (table 8 ). Such a scenario represents a physically active person whose inhalation rate would be higher than that of a person in a more sedentary occupation.

Comparison of the estimated absorbed dose of benzene for adults, infants, and children (tables 8 and 9) with the LOAELs (table 1) shows that concentrations to which the general population in the United Kingdom are exposed are well below all the reported LOAELs, in fact, three orders of magnitude lower than the estimated LOAEL for acute non-lymphocytic leukaemia.

\section{Discussion}

Most assessments of the potential adverse health effects of benzene have focused on occupationally exposed workers, in particular men. In attempting to evaluate the potential effect of environmental concentrations of benzene, this assessment has had to make many assumptions, depending on the availability and quality of data on exposures, health effects, and population characteristics.

The concentrations of outdoor benzene in the United Kingdom summarised in this paper are within the ranges reported elsewhere. Recent large scale studies in the United States and Canada, for example, have shown that mean outdoor air concentrations are in the range $1-8 \mu \mathrm{g} / \mathrm{m}^{3} .{ }^{39}$ In The Netherlands, studies have shown that in streets where cars are parked, concentrations of benzene indoors and at the front of houses can be 1.5-2 times higher than those measured at the back of the houses. ${ }^{70}$ This has been attributed to the evaporation of benzene from petrol tanks and engines. This source of benzene is likely to be as important in the United Kingdom as highlighted by the higher benzene concentrations reported near busy roads.

The values of indoor concentrations also seem to agree with those reported from other countries. ${ }^{39}$ In particular, the results showing the influence of an attached garage in increasing indoor air concentrations of benzene have also been found in studies in the United States. ${ }^{71}$ In the United Kingdom study by Brown and Crump ${ }^{62} 22 \%$ of houses had an attached garage, which, if typical, may indicate that this factor could affect a substantial proportion of the United Kingdom population.

Factors such as the number of smokers per household, how many cigarettes are smoked each day, and household characteristics such as room size and ventilation rates have been shown to influence exposure in the home. ${ }^{71}$ The fact that in 1995, in the United Kingdom, a mean of $29 \%$ of men and $27 \%$ of women were current smokers and that $47 \%$ of children (2-15 years) lived in households with at least one person who smoked ${ }^{72}$ highlights the importance of this source of indoor air exposure to benzene.

Various large scale studies from other countries have also highlighted the contribution that cigarette smoke makes to concentrations of benzene in indoor air. The United States total exposure assessment methodology (TEAM) studies have reported median concentrations of benzene in 200 homes without smokers to be 7 $\mu \mathrm{g} / \mathrm{m}^{3}$ compared with $10.5 \mu \mathrm{g} / \mathrm{m}^{3}$ in 300 homes with one or more smokers. ${ }^{73}$ Measurements in 230 homes in West Germany found very similar results, with median values of $6.9 \mu \mathrm{g} / \mathrm{m}^{3}$ in no-smoking homes and $9.3 \mu \mathrm{g} / \mathrm{m}^{3}$ in homes with smokers. ${ }^{74}$

In the United Kingdom, vehicle refuelling is mainly carried out by the customer. Under a proposed Stage II of the Petrol Vapour Recovery Directive 94/63/EC (PVR; EEC, 1994; OJ L365 31.12.1994), benzene emissions from petrol pumps were to be reduced by $70 \%$ by the year 2006. The European Union is no longer taking this directive forward. However, the Department of the Environment, Transport and the Regions is currently planning to implement a similar scheme. By taking into account the variety in shape of vehicle tank caps, erroneous manoeuvres by petrol attendants, accidental dysfunction of the system, and so on, the AgipPetroli study of service station employees estimated that the introduction of vapour-recovery systems would be capable of reducing the exposure of benzene emissions by $80 \%$ during "fuel in flow" and by $50 \%$ during removal and replacement of the nozzle and closure of the vehicle tank. This would reduce air concentrations during refuelling from 3709 $\mu \mathrm{g} / \mathrm{m}^{3}$ to $920 \mu \mathrm{g} / \mathrm{m}^{3}$.

Concentrations in vehicles reported in the United Kingdom studies are within the range of those reported elsewhere, which have generally found that mean exposure to benzene in vehicles can be in the order of three to 10 times greater than the background ambient concentrations. ${ }^{39}$ A recent Australian study reported benzene concentrations inside new cars as being around 11 times higher than ambient concentrations. ${ }^{75}$ This value was even higher for older cars without catalytic converters, where concentrations in vehicles during city driving were 27 times higher that ambient background concentrations, although concentrations dropped sharply in faster flowing motorway traffic. In general, concentrations in vehicles were about twice as high for cars without catalytic converters than for newer models with catalytic converters. This study showed that the pollution inside cars was a result of a combination of the cars' own exhaust emissions and those from the other vehicles on the road.

In general, studies in the United Kingdom of the relation between simultaneous measurements of outdoor, indoor, and personal levels of exposure have shown that mean personal air concentrations exceed indoor air concentra- 
tions, which in turn exceed outdoor air concentrations. Results obtained in the two United Kingdom studies ${ }^{63}{ }^{66}$ are in the range of those reported in the United States (3.2-24 $\left.\mu \mathrm{g} / \mathrm{m}^{3}\right) .{ }^{39}$ The mean personal exposure was about $15 \mu \mathrm{g} / \mathrm{m}^{3}$ with a range of $7-29 \mu \mathrm{g} / \mathrm{m}^{3}$. They also found that the overwhelming source of exposure to benzene for smokers was mainstream cigarette smoke. Smokers have a mean benzene body burden of about $6-10$ times that of non-smokers and receive about $90 \%$ of their exposure to benzene from smoking. ${ }^{39}$ In this paper, our assumptions give a figure of around $77 \%$ for the contribution from smoking. For non-smokers, most exposure to benzene was ultimately derived from vehicle exhaust or petrol vapour emissions, with a portion of exposure $(10 \%)$ being due to environmental tobacco smoke.

The calculation of absorbed daily doses was based on typical benzene concentrations in relevant microenvironments, time-activity patterns, and inhalation and absorption rates. Typical average figures from published studies have been used for time spent indoors, outdoors, and travelling. However, these are known to vary by such factors as age, sex, and employment. Infants and elderly people spend proportionately more time indoors than school age children and adults. Patterns also vary by day of the week and season, with more time generally spent outdoors during the summer months.

Average inhalation and absorption rates were used in this assessment. However, breathing rates are affected by numerous individual characteristics, including age, sex, weight, health, and level of physical activity (running, jogging, etc). Daily inhalation rates may also vary with exposure to lower environmental concentrations of benzene. Inhalation rates may be higher among outdoor workers and athletes because levels of activity outdoors may be higher. Therefore these population groups may be more exposed to air pollutants than the general population and could be considered to be high risk groups. ${ }^{76}{ }^{77}$ Mean inhalation rates of $0.2 \mathrm{~m}^{3}$ /hour have been estimated for periods of rest, and $0.3,0.5,1.0$, and $2.5 \mathrm{~m}^{3} /$ hour for sedentary, light, moderate, and heavy levels of activity, respectively. ${ }^{78}$

The absorbed daily doses were calculated for several scenarios. The estimated values are within the same range as those reported elsewhere in Europe. Oil Companies' European Organisation for Environment, Health and Safety, ${ }^{79}$ for example, estimated absorbed doses of $74 \mu \mathrm{g} /$ day for non-working, nonsmoking, non-driving residents in a rural environment and up to $458 \mu \mathrm{g} /$ day for office workers who smoke, drive, and live in an urban environment. Similarly, the United Kingdom Expert Panel on Air Quality Standards ${ }^{59}$ estimated daily intakes ranging from $120 \mu \mathrm{g}$ for a non-smoker living in an unpolluted rural area to $1250 \mu \mathrm{g}$ /day for a smoker living in a city.

The most significant potential adverse health effects from prolonged, low level exposure to benzene are haematotoxicity and carcinogenicity. Most quantitative risk assessments have been conducted with leukaemia as an end point as this is the most serious health risk associated with prolonged, occupational exposure.

The LOAEL for leukaemia for workers occupationally exposed to benzene has been estimated to be $32-80 \mathrm{mg} / \mathrm{m}^{3}$. However, because benzene is considered to be a genotoxic carcinogen, a safe or no effect level cannot be identified. Therefore many studies have used quantitative risk assessments or modelling to extrapolate from occupational exposures to estimate the risk to health from low level exposure to benzene.

It is important to note that there is continuing debate about the appropriateness of risk assessment with mathematical modelling. Also, the underlying mechanisms by which benzene causes cancer is not clearly understood, nor is it known whether the leukaemogenesis is related to average steady state or intermittent high peak exposure. Quantitative risk assessment with the linearised multistage model often used for carcinogens has been seriously challenged as unreliable and scientifically unsound, ${ }^{80}$ and the United Kingdom Committee on Carcinogenicity of Chemicals in Food, Consumer Products, and the Environment, for example, does not support the routine use of quantitative risk assessment for chemical carcinogens. Maynard et $a l^{\beta 1}$ proposed an alternative approach for the purpose of setting air quality standards and recommended a strategy based on the scientific data, decision points and uncertainty factors. Thus, although this review has presented the currently reported risk estimates for leukaemogenesis associated with benzene as the appropriate risk estimates for adverse health effects from low level exposure to benzene, it is possible that these estimates will change as the mechanism for carcinogenesis is further elucidated and more appropriate models, based on mechanistic considerations, emerge.

As previously noted almost all studies of the potential adverse effects of exposure to benzene have been carried out on adult male workers. Occupational exposure usually pertains to an 8 hour day, 5 days a week, for about 50 weeks a year, for $40-45$ years, whereas continuous exposure among the general population covers 24 hours a day, 7 days a week, for 52 weeks a year, for about 70 years. None the less, even for a worst case scenario, environmental exposure to benzene is several orders of magnitude lower than the lowest occupational exposures associated with adverse health impacts. Moreover, over the past 30 years car use and petroleum consumption has risen drastically. This has not been accompanied by an increased incidence of leukaemia.

It is always possible that some sectors of the population might be more susceptible to leukaemia induced by benzene. Children may be of particular concern; it could be argued that children's blood cells are dividing and maturing more rapidly, which could produce enhanced susceptibility to an environmental agent capable of causing leukaemia. However, the most prevalent type of leukaemia in children is acute lymphocytic leukaemia as 
opposed to acute myeloid leukaemia, the type which has been most strongly linked to exposure to benzene. In the United Kingdom, of the 66 children under 15 who died of leukaemia in 1995, 41 (62\%) died of acute lymphocytic leukaemia and $17(25 \%)$ died of acute myeloid leukaemia. ${ }^{68}$ Furthermore, it is also important to recognise that some of these leukaemias may be the result of exposure to radiation and viral infections, proved aetiological factors.

\section{Conclusions}

The major health risk associated with low level exposure to benzene is leukaemia and the strongest link in humans has been associated with acute non-lymphocytic leukaemia. To date few data have been found relating adverse health effects among women, children, or elderly people to exposure to benzene, as most studies have involved exposure of male workers. The lowest level of exposure at which an increased incidence of acute non-lymphocytic leukaemia among occupationally exposed workers has been reliably detected seems to be in the range of $32-80 \mathrm{mg} / \mathrm{m}^{3}$. Although some studies have suggested that effects may occur at lower concentrations, clear estimates of risk have not been assessed, partly because of the inadequacy of exposure data and the few cases. Overall, the evidence from human studies suggests that any risk of leukaemia to adults at general population continuous exposure concentrations of 3.8 to $42 \mu \mathrm{g} / \mathrm{m}^{3}$, which have been derived from available United Kingdom exposure data - that is, it is at concentrations three orders of magnitude less than the occupational lowest observed effect level - is likely to be exceedingly small and probably not detectable with current methods. The same approach applies for infants and children who may be exposed continuously to concentrations of $3.4-5.7 \mu \mathrm{g} / \mathrm{m}^{3}$. As yet there is no evidence to suggest that continuous exposure to environmental concentrations of benzene manifests as any other adverse health effect.

This work was undertaken as part of a contract from the Department of Environment, Transport, and the Regions. Thanks go to all the participants of a workshop held in Octobe 1997 for their comments.

1 Nielsen IR, Rea JD, Howe PD. Environmental hazard assessment: benzene (TSD/4). Watford, UK: Buildings Research Establishment, 1991.

2 Young RJ, Rinsky RA, Infante PF, et al. Benzene in consumer products. Science 1978;199:248.

3 World Health Organisation. Benzene. Geneva, Switzerland: WHO, 1993. Organisation. Benzene. Geneva, Switzerland: Safety, Environmental Health Criteria No150.)

4 Yu C, Crump D. A review of the emission of VOCs from polymeric materials used in buildings. Building Environment 1998;33:357-74

5 Etkin DS. Volatile organic compounds in indoor environments. Arlington, MA, USA: Cutter Information, 1996.

6 Salway AG, Eggleston HS, Goodwin JWL, et al. UK emissions of air pollutants 1970-95.Abingdon, UK. AEA Technology.1997. (AEAT-1746/Issue 1.)

7 Institute for Environment and Health. IEH report on benzene in the environment. An evaluation of exposure of the UK general population and possible adverse effects. Report R12. Leicester, UK: IEH, 1999 .

8 ATSDR. Toxicological profile for benzene. Atlanta GA, USA US Department of Health and Human Services, 1993. (TP-92/03)

9 Paustenbach DJ, Bass RD, Price P. Benzene toxicity and risk assessment, 1972-92: implications for future regulation. Environ Health Perspect 1993;101:177-200.
10 Black LF, Offord K, Hyatt RE. Variability in the maximal expiratory flow volume curve in asymptomatic smokers in nonsmokers. Am Rev Respir Dis 1974;110:282-92.

11 Hughes K, Meek ME, Bartlett S. Benzene: evaluation of risks to health from environmental exposure in Canada. fournal of Environmental Science and Health C 1994;12:16171.

12 Jex TT, Wyman DO. A mini review of benzene. Toxic Substance Mechanisms 1996;15:135-43.

13 Exxon Biomedical Sciences. Benzene risk characterisation. Eastmillstone, NJ, USA: EBS, 1996

14 Blot WJ, Brinton LA, Fraumeni JF, et al. Cancer mortality in US countries with petroleum industries. Science 1977;198: $51-3$.

15 Hearey CD, Ury H, Siegelaub A, et al. Lack of association between cancer incidence and residence near petrochemical industry in the San Francisco Bay area. F Natl Cancer Inst 1980;64:1295-9.

16 Kaldor J, Harris JA, Glazer E, et al. Statistical association between cancer incidence and major-cause mortality, and estimated residential exposure to air emissions from petroleum and chemical plants. Environ Health Perspect 1984;54: 319-32.

17 Knox EG. Leukaemia clusters in childhood: geographical analysis in Britain. F Epidemiol Community Health 1994;48: $369-76$

18 Wolff SP. Correlation between car ownership and leukaemia: is non-occupational exposure to benzene from petrol and motor vehicle exhaust a causative factor in leukaemia and lymphoma? Experimentia 1999;48:301-4.

19 McKinney PA, Alexander FE, Cartwright RA, et al. Parental occupations of children with leukaemia in west Cumbria, north Humberside, and Gateshead. BMF 1991;302:681-7.

20 Buckley JD, Robison LL, Swotinsky R, et al. Occupational exposures of parents of children with acute nonlymphocytic leukemia: a report from the children's cancer study group. Cancer Res 1989;49:4030-7.

21 Lowengart RA, Peters JM, Cicioni C, et al. Childhood leukemia and parents' occupational and home exposures. $\mathcal{F}$ Natl Cancer Inst 1987;79:39-46.

22 Clayton GD, Clayton FE. Patty's industrial hygiene and toxicology. New York, USA: John Wiley, 1994

23 Fishbeck WA, Townsend JC, Swank MG. Effects of chronic occupational exposure to measured concentrations of benzene. F Occup Med 1978;20:539-42.

24 Kipen HM, Cody RP, Goldstein BD. Use of longitudinal analysis of peripheral blood counts to validate historical reconstructions of benzene exposure. Environ Health Perspect 1989;82:199-206.

25 Rothman N, Li GL, Dosemeci M, et al. Hemotoxicity Rothman $\mathrm{N}, \mathrm{Li}$ GL, Dosemeci $\mathrm{M}$, et al. Hemotoxicity
among Chinese workers heavily exposed to benzene. $A m \mathcal{F}$ Ind Med 1996;29:236-46.

26 Lui L, Zhang Q, Feng J, et al. The study of DNA oxidative damage in benzene-exposed workers. Mutat Res 1996;370: 145-50.

27 Aksoy M, Erdem S, Dincol G. Leukemia in shoe-workers exposed chronically to benzene. Blood 1974;44:837-41.

28 Christie D, Robinson K, Gordon I, et al. A prospective study in the Australian petroleum industry. II: incidence of cancer. Br f Ind Med 1991;48:511-14.

29 Decoufle P, Blattner WA, Blair A. Mortality among chemical workers exposed to benzene and other agents. Environ Res 1983;30:16-25.

30 Hurley JF, Cherrie JW, Maclaren W. Exposure to benzene and mortality from leukaemia: results from coke oven and other coal product workers [letter]. Br F Ind Med 1991;48: 502-3.

31 Paxton MB, Chinchilli VM, Brett SM, et al. Leukaemia risk associated with benzene exposure in the Pliofilm cohort. I: Mortality update and exposure distribution. Risk Anal 1994;14:147-54

32 Rushton L. Further follow up of mortality in a UK oil distribution centre cohort. Br f Ind Med 1993;50:561-9.

33 Tsai SP, Wen CP, Weiss NS, et al. Retrospective mortality and medical surveillance studies of workers in benzene areas of refineries. F Occup Med 1983;25:685-92.

34 Vigliani EC, Forni A. Benzene and leukemia. Environ Res 1976;2:122-7.

35 Yin SN, Li GL, Tain FD, et al. A retrospective cohort study of leukemia and other cancers in benzene workers. Environ Health Perspect 1989;82:207-13.

36 Infante PF. Leukaemia in benzene workers. F Environ Pathol Toxicol 1979;2:251-7.

37 Rinsky RA, Young RJ, Smith AB. Leukaemia in benzene workers. Am F Ind Med 1981;2:217-45.

38 Rinsky RA, Smith AB, Hornung R, et al. Benzene and leukaemia: an epidemiologic risk assessment. $N$ Engl f Med 1987;316:1044-50.

39 Wallace L. Enviornmental expsoure to benzene: an update. Environ Health Perspect 1996;104:1129-36.

40 Austin H, Delzell E, Cole P. Benzene and leukaemia: a review of the literature and a risk assessment. Am $\mathcal{F}$ Epidemiol 1988;127:419-39.

41 Brett SM, Rodricks JV, Chinchilli VM. Review and update of leukaemia risk potentially associated with occupational exposure to benzene. Environ Health Perspect 1989;82:26781 .

42 Byrd DM, Barfield ET. Uncertainty in the estimation of benzene risks: application of an uncertainty taxonomy to risk assessments based on an epidemiology study of rubber hydrochloride workers. Environ Health Perspect 1989;82: 283-7. 
43 Crump KS. Risk of benzene: induced leukemia derived from the Pliofilm cohort: effect of additional follow up and new exp $219-42$.

44 Crump KS, Allen BC. Quantitative estimates of risk of leukaemia from occupational exposure to benzene. Washington DC, USA: US Department of Labour, 1984. (OSHA Docket H-059b, Exhibit 152, Annex B.)

45 Paustenbach DJ, Price PS, Ollison W, et al. Re-evaluation of benzene exposure for the pliofilm (rubberworker) cohort (1936-76). F Toxicol Environ Health 1992;36:177-231.

46 Rinsky RA. Benzene and leukemia: an epidemiologic risk assessment. Environ Health Perspect 1989;82:189-91.

47 Rinsky RA, Hornung R, Landrigan PJ. Re: Benzene and leukaemia: a review of the literature and a risk assessment. Am 7 Epidemiol 1989:5:1084 5.

48 Schnatter AR, Nicholich MJ, Bird MG. Determination of leukemogenic benzene exposure concentrations: refined

9 Paxton MB, Chinchilli VM, Brett SM, et al. Leukaemia risk associated with benzene exposure in the Pliofilm cohort. II. associated with benzene exposure in the P1.

50 Bond GG, McClaren EA, Baldwin CL, et al. An update of mortality among chemical workers exposed to benzene. $B$ F Ind Med 1986;43:685-91.

51 Hayes RB, Yin SN, Dosemeci M, et al. Benzene and the dose-related incidence of hematologic neoplasms in China. f Natl Cancer Inst 1997;89:1065-71.

52 Ireland B, Collins JJ, Buckley CF, et al. Cancer mortality among workers with benzene exposure. Epidemiology 1997, 8:318-20.

53 Wong O. An industry wide mortality study of chemical workers occupationally exposed to benzene. I: General results. Br F Ind Med 1987:44:365-81.

54 Ott MG, Townsend JC, Fishbeck WA, et al. Mortality among individuals occupationally exposed to benzene. Arch Environ Health 1978;33:3-10.

55 Wong O. An industry wide mortality study of chemical workers occupationally exposed to benzene. II: Dose workers occupationally exposed to benzene.
response analyses. $B r \mathcal{F}$ Ind Med 1987;44:382-95.

56 Rushton L, Romaniuk HM. A case-control study to investigate the risk of leukaemia associated with exposure to benzene in petroleum marketing and distribution workers in the United Kingdom. Occup Environ Med 1997;54:152-66.

57 Schnatter AR, Katz AM, Nicolich MJ, et al. A retrospective mortality study among Canadian petroleum marketing and distribution workers. Environ Health Perspect 1993; 101(suppl 6):85-99

58 AEA. Air pollution in the UK: 1995. Abingdon UK. AEA Technology, 1997

59 EPAQS. Benzene. London. The Stationery Office, 1994

60 DoE. United Kingdom national air quality strategy. London, UK: The Stationery Office, 1997. (CM 3587.)

61 Crump DR. Indoor air pollution. In: Davison G, Hewitt $\mathrm{CN}$, eds. Air pollution in the United Kingdom. Cambridge, UK: The Royal Society of Chemistry, 1997,

62 Brown VM, Crump DR. Volatile organic compounds. In Berry RW, et al, eds. Indoor air quality in homes, part 1. LonBerry RW, et al, eds. Indoor air quality in homes, part 1. Lo

63 Leung PL, Harrison RM. Evaluation of personal exposure to monoaromatic hydrocarbons. Occup Environ Med 1998 55:249-57.

64 CONCAWE. Review of european oil industry benzene exposure data (1986 -1992). Brussels, Belgium: Oil Companie European Organisation for Environment, Health and Safety, 1994. (CONCAWE Report No 7/94.)

65 SCAQMD. In vehicle characterisation study in the south coast air basin. Los Angeles CA, USA. South Coast Air Quality Management District, 1989.

66 Mann HS, Crump DR, Brown VM. The use of diffusive samplers to measure personal exposure and area concen- trations of VOCs including formaldehyde.. Healthy Buildings 1997;3:135-40

67 Hedgecott S, Lewis S. An update on proposed environmental quality standards for benzene in water. London, UK: Department of the Environment, 1997. (DoE 4287/1.)

68 MAFF. Benzene and other aromatic hydrocarbons in food: average UK dietary intakes. London, UK: Ministry of Agriculture, Fisheries and Food, 1995. (Food surveillance information sheet number 58.)

69 Brunnemann KD, Kagan MR, Cox JE, et al. Determination of benzene, toluene and 1,3-butadiene in cigarette smoke by GC-MSD. Exp Pathol 1989;37:108-13.

70 Bloeman HJT, Balvers TM, Lebret E, et al. Living in streets with high traffic density: exposure assessment. In: The 5th International Conference of the International Society for Environmental Epidemiology. Stockholm, Sweden: Institudte of Environmental Medicine, 1993.

71 Ashmore M, Loth K. Assessment of personal exposure to air pollution: a review of current knowledge and research needs for the UK. London, UK: Imperial College Science and Technology, 1994.

72 Prestcott-Clarke P, Primatesta P. Health survey for England and Wales 1995. Vol 1. Findings. London UK: Stationery Office, 1997.

73 Wallace LA. Major sources of benzene exposure. Environ Health Perspect 1989;82:165-9.

74 Krause C, Mailahn W, Nagel R, et al. Occurence of volatile organic compounds in air of 500 homes in the Federal Republic of Germany. In: Proceedings of the 4th International Conference on Indoor Air Ouality and Climate. Berlin, Germany: Institute for Water, Soil, and Air Hygiene, 1987; 102-6.

75 Duffy BL, Nelson PF. Exposure to emissions of 1,3butadiene and benzene in the cabins of moving motor vehicles and buses in Sydney, Australia. Atmosphere and the Environment 1997;31:3877-85.

76 Shamoo DA, Johnson TR, Trim SC, et al. Activity patterns in a panel of outdoor workers exposed to oxidant pollution. 7 Expo Anal Environ Epidemol 1991;1:423-38.

77 Linn WS, Shamoo DA, Hackney JD. Documentation of activity patterns in high-risk groups exposed to ozone in the Los Angeles area. Pittsburgh: Air and Waste Management Angeles area. Pittsburgh:

78 Layton DW. Metabolically consistent breathing rates for use in dose assessments. Health Phys 1993;64:23-6.

79 Knudson RJ, Slatin RC, Lebowitz MD, et al. The maximal expiratory flow-volume curve. Am Rev Respir Dis 1976;113: 587-600

80 Lovell DP, Thomas G. Quantitative risk assessment and the limitations of the linearised multistage model. Hum Exp Toxicol 1999;15:87-104.

81 Maynard RL, Cameron K, Fielder RJ, et al. Setting air quality standards for carcinogens: an alternative to mathematical quantative risk assessment: discussion paper. Hum Exp Toxicol 1995;14:175-86.

82 Thienes CH, Haley TJ. Clinical toxicology. Philadelphia: Lea and Febiger, 1972.

83 Yin $\mathrm{SN}, \mathrm{Li} \mathrm{Q}$, Liu $\mathrm{Y}$, et al. Occupational exposure to benzene in China. Br f Ind Med 1987;44:192-5.

84 Greenburg L, Mayers MR, Goldwater L, et al. Benzene (benzol) poisoning in the Rotogravure printing industry in New York City. Fournal of Industrial Hygiene and Toxicology

85 Aksoy M, Dincol K, Erdem S, et al. Details of blood changes in 32 patients with pancytopenia associated with long-term exposure to benzene. Br F Ind Med 1972;29:56-64.

86 Downing CEH, Campbell GW, Bailey JC. A survey of sulphur dioxide and hydrocarbon concentrations in the United Kingdom, using diffusion tubes: Fuly to December 1992. Stevenage, UK: Warren Spring Laboratory, 1994. (L4 964.)
Answers to multiple choice questions
(1) (a) True (b) True (c) False (d) False (e) True
(2) (a) False (b) True (c) False (d) True (e) False
(3) (a) False (b) False (c) True (d) True (e) False
(4) (a) False (b) True (c) True (d) True (e) False
(5) (a) False (b) False (c) False (d) True (e) False 